\title{
The PDS Tests the West: the Party of Democratic Socialism's Campaign to become a pan-German Socialist Party
}

Since German reunification the post-communist Party of Democratic Socialism (PDS) has been widely regarded as the articulator of eastern German interests within the political system of the Federal Republic. However the party's leadership does not want it merely to be a regional interest party, but a 'modern socialist party' with nationwide support. This article considers why the PDS wants to build support in the West of Germany and outlines some of the strategies employed to achieve this. It examines the nature and composition of the western PDS, and offers explanations for the party's electoral performance in the West. Finally, a case study of the party's attempts to transcend the east-west divide in Berlin will be presented. The reunited city is the only eastwest Land of the 16 that comprise the Federal Republic, hence western Berlin provides the PDS with a testing ground for its strategies for western expansion in general. The article argues that the party is unlikely to achieve a break through in the West of Germany, unless it abandons its self-proclaimed special responsibility to serve eastern interests. Furthermore, an east-west conflict prevails within the PDS which has both cultural and ideological dimensions, which could prove divisive in such a heterogeneous party. 
The German Federal election of 2002 may have marked the beginning of the end for the Party of Democratic Socialism (PDS), at least as a political actor at federal level. Until then, the party, which is directly descended from the ruling communist party of the GDR, the Socialist Unity Party (SED), had defied its critics and increased its vote share at every successive federal election. Over the past decade scholars and journalists have tried to categorise the PDS, either as a protest party, an anti-system party, a milieu party, a socialist reform party, or a regional party. ${ }^{1}$ Of all these categories, the latter is perhaps the most convincing, given that the party's support is concentrated in eastern Germany, although it does combine elements of all these labels. Dan Hough sees similarities between the PDS and other European regional/nationalist parties, and concludes: 'the PDS is not a socialist party that happens to be particularly strong in one region of the country; rather, it is a regional party built on socialist principles'. ${ }^{2}$ Indeed, the PDS is often described as the 'CSUOst', thereby equating it with the Christian Social Union, which has successfully survived in the post-war German party system as the articulator of Bavarian interests.

However, the key difference between the PDS and other regional parties is that it does not want to operate only in eastern Germany. Instead it claims to be a modern socialist party for all Germans, albeit one with special responsibility for the East. The party's aim of building support in western Germany is the focus of this article. The article considers why the leadership of the PDS advocates western expansion and to what extent this has the support of the majority of the party. It looks at the strategies employed to achieve this aim, and to what extent they have been successful. Particular reference is made to the 2002 federal election. It also looks at the nature and composition of the western PDS. Finally, a case study of the party's attempts to 
transcend the east-west divide in Berlin will be presented, since the reunited city is the only 'east-west Land' in the Federal Republic and as such, has provided the PDS with a testing ground for its strategies for western expansion in general.

In short, the party is attempting to exploit a centre-periphery cleavage, or perhaps more accurately, a territorial-cultural cleavage, ${ }^{3}$ and a class cleavage simultaneously. This has generated an east-west conflict within the party, with territorial and ideological dimensions. Even so, as this article demonstrates, the party leadership is unwilling to accept that its federal ambitions are incompatible with the reality of its eastern German appeal, and that the western expansion campaign is unlikely to succeed.

THE PDS: A MODERN SOCIALIST PARTY FOR THE WHOLE OF GERMANY?

No other German party enjoys such a markedly different level of support in the east and west of the Federal Republic as the PDS. Ironically its concentrated support in the eastern Länder secured its position in German politics at federal level. In particular its strongholds in East Berlin used to provide the party with a safety net because any party winning three constituency seats (which are contested using a majoritarian system) automatically gains entry into the Bundestag, even if its overall proportion of the national vote is below five percent. ${ }^{4}$ The eastern PDS is also highly heterogeneous encompassing a wide range of political views and appealing to people from different backgrounds. A cursory glance at the list of party organisations and subgroups illustrates this point, from the notorious Communist Platform on the one hand, to the Working Group for Christians on the other. The party certainly cannot be accused of censoring diverging views, and both the aptly named party magazine 
'Disput' and individual members' websites feature articles at odds with the federal party line.

The party's aim to increase support in the western Länder (known as Westaufbau or Westausdehnung) is not new, but it has grown in prominence in material produced by the federal party in recent years, in particular for the federal election of 2002. So too has the emphasis on the party's socialist credentials at the expense of its eastern roots and responsibilities. While its views on the role of the state in social policy and on international affairs place it well to the left of the Social Democrats (SPD), it is hardly a traditional workers' or communist party, in spite of the presence of small factions who would like it to be. The Party Programme, dating back to 1993, concentrates on the party's responsibility to represent the interests of eastern Germans who it claims are discriminated against in reunited Germany. However it also mentions the need for co-operation between socialists in eastern and western Germany and the party's commitment to operate across the Federal Republic, in spite of its eastern heritage. ${ }^{5} \mathrm{~A}$ new Party Programme will be voted on at the party conference in October 2003 which retains the claim to be a 'democratic and emancipatory, modern socialist party, operating nationwide'. ${ }^{6}$ The party’s federal election manifestos have reiterated the claim to be a genuine federal party. The 1998 manifesto emphasised its socialist policies and explicitly stated: 'We want to represent these goals nation-wide, in the West as well as the East. They determine our special responsibility in Eastern Germany, not as a regional party, but as a socialist party for the Federal Republic., ${ }^{7}$ According to the manifesto, many of eastern Germany's problems were merely the heightened difficulties of the country as a whole. In the manifesto for the 2002 federal election the portrayal of the PDS as a socialist party for Germany as a whole was even more marked. Only one section dealt with eastern Germany specifically and 
reference was made to the need to stop thinking and acting along east-west lines. ${ }^{8}$ The message would appear to be that the PDS, as a socialist party, stands up for the socially disadvantaged and for minorities who lack a political voice, and many eastern Germans fit these categories in today’s Federal Republic.

However, references to discrimination against eastern Germans and to reunification as the 'annexation of the GDR', and criticism of attempts to 'westernise' eastern Germany in other party documents may undermine the party's appeal to western Germans. This is the key dilemma for the PDS: can it maintain its support in the eastern Länder, while simultaneously attempting to appeal to left-wingers in the western Länder with socialist rhetoric? In other words, can it simultaneously benefit from territorial-cultural and class cleavages? This dilemma was highlighted by arguments provoked by the publication of the 'Rostock Manifesto' in the spring of 1998 - a document that focused specifically on the economic situation in the eastern Länder. A particularly controversial proposal was a veto right for the eastern Länder in the upper house, the Bundesrat. To critics the manifesto appeared to be an admission that the PDS was essentially an eastern German regional party and an acknowledgement of the failure of its western expansion plans. ${ }^{9}$

The campaign to increase support in the West enjoys the support of many highly influential figures within the party. They include the current federal Chair Lothar Bisky, and his predecessor, Gabi Zimmer, the party’s chief ideologist André Brie, and the PDS’s best known politician, former parliamentary party leader, Gregor Gysi. The campaign is also supported by the far left within the party, including the high profile Communist Platform and the Marxist Forum since their agendas are more ideological than regional. 
However, opponents of the western expansion campaign have not remained silent. One of the most outspoken is Christine Ostrowski, a former Bundestag MP from Saxony, who together with a colleague published a 'Letter from Saxony' in 1996, which sparked a widespread debate about the party’s objectives and identity. The document overtly called for the abandonment of the PDS's western expansion plan and for its self-promotion as an eastern German people's party. The authors claimed that the attempt to establish the PDS in the West had failed, in spite of the injection of material and personal resources. They advocated co-operation between the eastern PDS and existing western left-wing groups, as opposed to courting the western left, which might hinder the consolidation of the PDS as an eastern German people’s party. They also argued that what the party understood by 'modern socialism' should be determined by the day-to-day experiences of its millions of supporters in the eastern Länder. ${ }^{10}$ The 'Letter from Saxony' challenged official party policy, and highlighted a fact obvious to most outsiders, namely that the aim of representing eastern interests was (and is) incompatible with the aim of western expansion. A second 'letter' followed stating that while the PDS leadership might want the support of western Germans, the latter clearly did not want the PDS. ${ }^{11}$ The two 'letters' provoked considerable criticism, especially from western German members and from the Communist Platform. ${ }^{12}$ Furthermore, an extensive survey of PDS members carried out in 2000 revealed that only 17 per cent of eastern members believed the party should remain an Ost-Partei. ${ }^{13}$

Given that the representation of eastern interests appeared to be a winning strategy for the PDS, and that it can make a reasonable claim to be an eastern German people’s party based on its ability to attract voters from most social groups, ${ }^{14}$ why does the leadership want to expand westwards? The first reason is to gain over the five per 
cent of the vote in federal elections in order to stay in the Bundestag, thereby retaining a voice in German politics at federal level. ${ }^{15}$ This became even more crucial at the 2002 election because the party could no longer expect to win at least three constituency seats (Direktmandate) in Berlin due to constituency boundary changes. In percentage terms the aim in 2002 was to achieve at least six per cent of the federal vote, based on 25 per cent in the eastern Länder and two percent in the West. ${ }^{16}$ The latter objective was regarded as the key to the party’s survival at federal level, should polls suggesting the party's support in the East had peaked prove to be correct. ${ }^{17}$ The second reason for the desire to 'go west' is linked to the party's claim to be a 'modern socialist party', as opposed to an eastern German regional party. This claim would have more credibility if the gap between the party's vote share in the east and west of the country could be narrowed, and would give the PDS more legitimacy in the German political system as a whole. Asked why the PDS does not accept that it is the 'CSU of the East', former parliamentary party leader, Roland Claus replied, 'We cannot discriminate against western German voters and deny them an important party like the PDS'. ${ }^{18}$

\section{PDS ACTIVISTS FROM THE WESTERN LÄNDER}

The PDS currently has nearly 5,000 members in the West. ${ }^{19}$ The largest Land branch is in North Rhine-Westphalia, which has over 1,000 members, while others have 100600 members. In contrast there are around 74,000 members in the East. Saxony alone has nearly 20,000, Berlin and Brandenburg over 13,000 each. However, over the past few years membership levels have risen slightly in the West (up 600 compared with 2001), whereas in the East where they have fallen substantially. ${ }^{20}$ 
However, differences between the eastern and western PDS are not only quantitative. The eastern PDS is dominated by pensioners who are attracted to a party composed of like-minded eastern Germans. In 200168 per cent of eastern members were over 60 years old and only nine per cent under 40 . In contrast the western PDS has a younger membership, with 35 per cent of members under 30 years old, and a further 29 per cent under $40{ }^{21}$ These age differences inevitably affect the social structure of the membership in eastern and western Germany. Pensioners are under represented in the western PDS (just eight per cent in 2001), and more western members are employed or self-employed (57 per cent compared with 31 percent). A much higher proportion of western members are students and the party's election results in western university towns are usually well above the western average. ${ }^{22}$ The western PDS is also more masculine - in 2000 three-quarters of members were male, whereas in the east 57.5 per cent were male, 42.5 per cent female. ${ }^{23}$ In terms of voters however, the situation is very different. The PDS attracts voters from all ages and backgrounds in the East, not just those who would describe themselves as socialists, hence the label 'people's party of the East'. In contrast its potential electorate in the West is very narrow and same is true of its membership. While many easterners support the PDS out of a sense of regional and cultural identification, western members are a motley collection of left-wingers in search of a political home. They include former members of other parties with little hope of electoral success such as the German Communist Party (DKP), ${ }^{24}$ and former members of the SPD and Greens who are disillusioned by the record of the Red-Green federal government. In addition, according to André Brie, the PDS attracts young and first-time voters in the West who do not share their elders' prejudices towards eastern Germany which date back to the Cold War. ${ }^{25}$ 
A further difference between eastern and western branches of the PDS is that in the East the party has made the transition from opposition to government (in Mecklenburg-Vorpommern and Berlin). As a consequence it has become more pragmatic and more involved with day-to-day problem solving, not to mention compromised by the dynamics of coalition government. In addition, senior figures from the eastern Länder such as Gregor Gysi, Gabi Zimmer and Petra Pau, have tried hard to appear competent and professional in public. In contrast the western PDS is more of a radical fringe party, which often appears to be amateur and riddled with sectarianism. Also, with little chance of gaining seats, western branches inevitably place more emphasis on opposition (especially extra-parliamentary opposition) compared with their eastern counterparts who have to play by the rules, either as opposition parties in parliaments or even in government. The Hamburg PDS in particular brought the western PDS into disrepute, with years of division, allegations of undemocratic elections of officers, and infiltration by an extreme left-wing student group. The federal leadership accused the group of working against the interests of the PDS as a whole ${ }^{26}$ and derided the Hamburg branch as a 'free floating ideology brigade'. ${ }^{27}$

Major cultural and ideological differences exist between PDS members in the east and west of Germany, as the federal leadership is well aware. ${ }^{28}$ The aforementioned members' survey revealed that 79 per cent of eastern members and 73 per cent of western members believed there were too many misunderstandings and conflicts between the two camps. ${ }^{29}$ While the party in the East concerns itself with practical issues such as social justice and the equality for East Germans, many members in the West cling to orthodox views of class conflict, and have a reputation for being more interested in debating Marxism and dreaming of the revolution than devising concrete 
solutions to social problems. Because a large proportion of Eastern members do not hold radical left-wing views, the more ideologically motivated western activists regard many eastern PDS voters as the 'wrong kind' of supporters who may have to be shed in order to attract the 'right kind', namely socialists in the West. ${ }^{30}$

Ideological differences between the eastern and western PDS came to a head with a row over patriotism in 2000. The then federal chair, Gabi Zimmer, used the phrase 'I love Germany’ in a speech and claimed she saw nothing wrong with using words such as 'patriotism', 'nation' and 'Germany' ${ }^{31}$ Zimmer was accused of Deutschtümelei (hypergermaness) $^{32}$ by western activists, and by some eastern left-wingers who claimed that words such as 'nation' and 'Germany' were the preserve of the far right and irrelevant for the cause of socialism. They also believed that such language would offend left-wingers in western Germany, thereby further reducing the party’s low levels of support there. ${ }^{33}$ Overall the acrimonious debate highlighted how the mission of the PDS was perceived differently by eastern and western members. For the former it remained a party with special responsibility for the interests of all East Germans, while for the latter its role was defined in terms of the class struggle. The debate provoked fears of a split between the territorially orientated and the ideologically driven factions and of the end of the PDS as an all-German project. ${ }^{34}$

Following the PDS's federal election defeat in 2002 many of the party's federal executive declined to stand for reelection. Most of those who stood down were members of the party's reformist wing and their departure allowed orthodox leftwingers, including several from the West, to take over key roles including deputy party chair and party secretary. ${ }^{35}$ Clashes between these two individuals and the then federal chair, Gabi Zimmer, over the future direction of the party soon made the new executive unworkable, and provoked the most serious leadership crisis since the 
foundation of the party. The party secretary had accused the eastern branches of trying to turn the PDS into an eastern regional party, subservient to the SPD, and claimed that only the 'wisdom of the western left' could transform the PDS into a proper nationwide socialist party. However other party speakers from the West publicly distanced themselves from these comments, claiming that the PDS's strength in the East was a precondition for its growth in the West. ${ }^{36}$ After just eight months in office both Frau Zimmer and the federal executive resigned in June 2003. A new executive was elected, headed by Lothar Bisky, with all the key positions back in the hands of Easterners. ${ }^{37}$ Bisky, a reformer and supporter of the PDS's western expansion, had been federal chair from 1993-2000 and was widely regarded as the only individual who could lead the party out of its ideological crisis and prevent further electoral defeats.

In short, while for other parties in the Federal Republic the eastern or western German origins of members are increasingly irrelevant, the same cannot be said of the PDS. According to some western activists, they are still not considered to be a normal part of the party and they feel badly treated by the eastern majority. They have accused outspoken eastern politicians like Christine Ostrowski of 'eastern fixated arrogance' ${ }^{38}$ In the words of one commentator, the western PDS members are the Ossis of the party, treated worse by the leadership than eastern members of western-based parties. $^{39}$

\section{STRATEGIES FOR BUILDING SUPPORT IN THE WESTERN LÄNDER}

Over the past three years the PDS's election campaigns in western Germany have been noticeably more active, although a coherent strategy to be used across the 
western Länder does not appear to exist. The federal party leadership allows individual PDS Land branches to decide whether or not to field candidates in elections since there are clearly instances when to do so would be a waste of time and money. For example the Land branch in Bavaria decided not to contest the Land election in September 2003. ${ }^{40}$

Unlike in the eastern Länder, where the PDS can rely on the allegiance of a certain number of voters simply by virtue of its origins, to appeal in the West it has to come up with some convincing socialist arguments, and to offer something distinctive from the other left-of-centre parties. To this end the PDS has adopted two key issues: social justice and peace. The first opportunity to enhance its image as an anti-war party arose in 1999 with the Kosovo crisis. The approval of the Nato bombing campaign by the red-green coalition government, and the subsequent participation of German troops in the Nato operation provided the PDS with the chance to present itself as Germany's only anti-war party and to appeal to pacifists within the Greens and SPD. The crisis also encouraged unprecedented east-west co-operation within the party and with other pacifist groups. ${ }^{41}$ A similar opportunity arose in 2001 when USled bombing of Afghanistan began, supported by the federal government.

A second key strategy in the West has been the targeting of urban city centres and university towns. For example, in local elections in Lower Saxony in the autumn of 2001, Hanover, Göttingen and Oldenburg were particular targets. A third strategy has been to gain representation in district and city councils. In the words of the former chief whip, Dietmar Bartsch, 'In the West too, the house of the PDS will be built from below via steadfast, committed effort on the ground. ${ }^{42}$ This strategy had proved highly successful in the eastern Länder, where the PDS has cultivated its image as an everyday party (Alltagspartei) for ordinary people and for implementing policies that 
have an impact on people's daily lives. An advantage of this approach is that there is no five-percent hurdle to overcome in order to gain seats in local councils, as is the case in Land and federal elections, therefore even a tiny proportion of the vote can bring representation.

An additional strategy has been to forge links with other organisations with a leftwing agenda, such as trade unions, women's groups, and the remnants of the German Communist Party (DKP). The PDS and DKP occasionally put up joint candidates in local elections in the West, in spite of a resolution passed at the annual party congress in Schwerin in 1997, according to which members of other political parties may not stand for the PDS, although non-party members may.

Various other methods have been used to raise the PDS's profile in the West including: rallies led by the charismatic Gregor Gysi; a western venue for the party’s annual conference in 2000 (Münster); the nomination of a western German candidate for the post of Federal President in 1999; crash courses for new activists in the West; and the creation of a 'Kommunalforum West' in target Länder such as Lower Saxony and Hessen to serve as a forum for the exchange of experiences and strategies. ${ }^{43}$ However, not all initiatives have worked. Attempts to encourage left-wing singers and songwriters in the West to support the PDS failed, largely because they feared such a connection would damage their careers. ${ }^{44}$

While many of these strategies were essentially PR exercises, aiming to show a PDS presence in the West to prevent it being ignored, practical measures have also been used to help the struggling western branches. A major problem is the shortage of western members - unlike in the East where there are plenty of members to do the 'donkey work', notably pensioners with time to spare (dubbed Turborentner ${ }^{45}$ ). Consequently easterners have been dispatched to the West to swell the numbers of 
activists. Co-operation has been organised between neighbouring Land branches such as Thüringen and Hessen. In addition to human resources, the federal party has injected financial resources into western election campaigns, ${ }^{46}$ most notably for the 2002 federal election. To support the drive westwards, election campaign manager, Dietmar Bartsch, launched an initiative to encourage all members to donate $€ 8$ to party coffers to fund the election campaign. Of that, €4 would go to the donor's own Land branch, $€ 1.60$ to the federal party, and $€ 2.40$ to help the western party branches. $^{47}$

Initially party leaders had regarded the 2002 election as the best chance ever to increase (even double) PDS support in the West, and former federal chair, Gabi Zimmer, described the Westaufbau as a matter of importance for the whole party. ${ }^{48}$ Winning more votes in the West was regarded as crucial if the party were to clear the five per cent hurdle and most branches pledged their willingness to 'do their bit' to ensure this occurred. Two factors made this objective seem achievable: firstly, the red-green federal government had once again given the PDS the opportunity to portray itself as the country's only peace party; ${ }^{49}$ and secondly, the party's membership levels had risen in the West since the last federal election.

The party's federal election manifesto gave three key reasons why voters should vote for the PDS in 2002: firstly, because it was the party of social justice; secondly, because it was an anti-war party; and finally, because it envisaged a future for eastern Germany. Compared with previous manifestos however, very little related purely to eastern Germany, merely two and a half pages in a 26 page document, mainly referring to the opportunities the eastern enlargement of the EU would offer to the region. ${ }^{50}$ Instead the PDS claimed to stand for 'real unity between east and west ${ }^{\text {" }}$ " as opposed to being the voice of eastern Germans. Documents and internet pages 
produced by western branches of the PDS for the federal election made no mention of the party's special responsibility for the East, nor of its origins as successor to the SED. The western branches focused their campaign on social justice, unemployment, anti-racism, and peace issues. A key strategy was co-operation with social movements with interests in common with the PDS, in particular, trade unionists, peace movements, and anti-globalization protesters. ${ }^{52}$

The first blow to the party's nation-wide election campaign was the resignation of its star performer, Gregor Gysi, then economics minister in the Berlin senate, following a minor scandal. ${ }^{53}$ This sudden development was greeted with dismay by Land branches in the West, ${ }^{54}$ because Gysi was one of the few PDS politicians who was well known there, and both the party and the media believed he had helped secure a good result for the PDS in West Berlin in 2001 (see below). Two years earlier Gysi had resigned as leader of the parliamentary party at the stormy party conference in Münster. The Communist Platform had criticised the timing of his resignation, claiming that it had cost two per cent of votes in the Land election in North RhineWestphalia in 2000. The group argued that Gysi and other leading figures were less committed to the western expansion of the party than they claimed. ${ }^{55}$ Lacking one individual who could step into Gysi's shoes, the 2002 federal campaign focused on the foursome of Gabi Zimmer, Petra Pau, Dietmar Bartsch and Roland Claus, all eastern Germans. The second blow during the campaign was Chancellor Schröder's unambiguous rejection of German involvement in a future war with Iraq, thereby stealing the mantel of peace party from the PDS. From this point on, the PDS's ratings in the opinion polls plummeted, and it appeared the party would not even hold on to its core eastern voters, let alone double its previous result in the West, predictions which proved to be correct. 


\section{ELECTORAL SUPPORT FOR THE PDS IN WESTERN GERMANY}

Election results in the West suggest that the PDS's message still fails to appeal to western Germans. The party usually polls less than two per cent for federal and Land elections, compared with 20-25 per cent in the East until the downturn at the 2002 federal election. What is surprising however, is how after every disappointment in the West the party looks forward to the next opportunity to improve its performance there. With ten western Länder, each with different cycles for local and Land elections, the next electoral challenge is never far away.

TABLE 1: VOTES FOR THE PDS IN FEDERAL ELECTIONS (IN PER CENT)

\begin{tabular}{|l|l|l|l|}
\hline Year & East & West & FRG \\
\hline 1990 & 11.1 & 0.3 & 2.4 \\
\hline 1994 & 19.8 & 1.0 & 4.4 \\
\hline 1998 & 21.6 & 1.2 & 5.1 \\
\hline 2002 & 16.8 & 1.1 & 4.0 \\
\hline
\end{tabular}

Source: Bundeswahlleiter. NB. unless otherwise stated, Berlin is classed as an eastern Land.

Federal Elections 
Table 1 shows the huge difference between the PDS's support in the eastern and western Länder in federal elections. In percentage terms the party’s results in western Germany for the last three federal elections have been very consistent. However, the actual number of votes won in the West in 2002 was 411,762, approximately 16,000 fewer than in $1998 .^{56}$ Only in Hamburg and Bremen did the party poll over two per cent of the vote. However the party's disappointing performance in the West was overshadowed by its disastrous overall result, which saw the PDS Fraktion shrink from 37 (including five members from western Länder) to just two. However, due to surprisingly heavy loses in the East, the western vote as a proportion of the PDS's overall vote grew from around a sixth in 1998 to nearly a quarter in $2002 .^{57}$

\section{Land and Local Elections}

Even with a proportional representation electoral German system, many voters may be deterred from voting for small parties because their vote will be wasted if the party fails to clear the five percent hurdle. However, as mentioned earlier, this deterrent does not apply for local elections and may explain why the PDS has had some success at this level in the West. In total the PDS currently has over a hundred seats in local assemblies in the western Länder. ${ }^{58}$ In local elections in North Rhine-Westphalia in 1999 a result of just 0.8 per cent translated into 54 seats for the PDS in local assemblies, and the party even gained Fraktionstatus in the town council in Duisburg with a result of 4.2 per cent. ${ }^{59}$ This encouraged the Federal PDS to invest 500,000 DM (€250,000) in the Land election in North Rhine Westphalia in $2000,{ }^{60}$ which proved to be a disappointment, with an overall result of just 1.1 per cent. This 
provoked an acrimonious debate regarding the validity of standing in western Land elections, especially in view of the cost incurred. ${ }^{61}$

In 2001 the PDS targeted the local elections in Hessen. The election campaign had concentrated on five cities, most with universities, a strategy that appeared to pay off, as the results below show. The local party put up joint candidates with the DKP and Marxist List in certain towns, and received help from eastern PDS branches. Although the party polled only 0.4 per cent overall in Hessen (around 737,000 votes), it won 20 seats at local level. ${ }^{62}$ The local party heralded this rather modest result as 'a great success ${ }^{63}$ and former deputy party chair, Diether Dehm, claimed the PDS could win 3 per cent of the vote in Hessen at the 2002 federal election. ${ }^{64}$ (It polled 1.3 per cent). However others thought co-operation with an unreformed communist party like the DKP was bad for the PDS's image in the West. ${ }^{65}$

TABLE 2: RESULTS IN COUNCIL ELECTIONS IN HESSEN TARGETTED BY THE PDS IN 2001 (PER CENT)

\begin{tabular}{|l|l|l|}
\hline Town & 2001 & 1997 \\
\hline Marburg & 6.4 & 6.2 \\
\hline Gießen & 3.2 & 1.7 \\
\hline Kassel & 3.2 & - \\
\hline Offenbach & 2.8 & 2.3 \\
\hline Frankfurt & 2.3 & 1.6 \\
\hline
\end{tabular}

Source: 2001: Hessisches Statistisches Landesamt. 
Similar strategies were employed for the local elections in Lower Saxony in September 2001. As in Hessen, even the smallest gains were celebrated, notably the increase in local mandates from six to 13 and the achievement of Fraktionsstatus in the city councils of Göttingen and Oldenburg.

Apart from in West Berlin, which is dealt with separately below, other recent elections have proved disappointing for western PDS branches. The Land election in Hamburg in September 2001 was little short of a disaster, with the PDS polling 0.4 per cent. Internal problems within the local party were largely to blame, plus the existence of rival parties which could attract dissatisfied former Green and SPD supporters, such as the Rainbow Group, which polled 1.7 per cent. In local elections in Bavaria in March 2002, concentrated campaigns in the cities of Munich and Nuremberg produced only one local councillor. The disappointing result was largely put down to difficulties campaigning in such a large Land with only 500 members. ${ }^{66}$ The next test came in local and Land elections in Bremen in May 2003. With several Western Germans on the federal party executive at the time, the federal party called on all Land branches to support their colleagues in Bremen and donated €100,000 from central party coffers to help finance the election campaign. ${ }^{67}$ However, now almost invisible at federal level, the PDS seemed even less relevant to the voters of Bremen, only 1.67 per cent of whom voted PDS, compared with 2.8 per cent in 1999. ${ }^{68}$

While the PDS's electoral support in the West is consistent, in real terms it remains very low. What is remarkable is the continued optimism of local activists in the West, and their ability to look forward to the next election opportunity in spite of disappointing election results, dismissive remarks from the media, and less than whole-hearted support from the bulk of the party in the East. 


\section{EXPLAINING THE PDS'S POOR PERFORMANCE IN THE WEST}

Various factors help to explain why the PDS has failed to establish itself in western Germany. The most obvious is the simple fact that in both the East and the West of the Federal Republic the party is perceived by the public as an eastern regional party, as opinion polls confirm. ${ }^{69}$ Many of the PDS's activities reinforce this view, for example, campaigns to increase pensions for eastern Germans, to save street names commemorating communist heroes from GDR times, ${ }^{70}$ and to preserve the asbestosridden Volkskammer (People’s Chamber) in East Berlin. Senior members of the party leadership admit that the party's image as an East German regional party is 'a hindrance for the broader acceptance of the PDS as the representative of people's social interests in the old Länder'. ${ }^{71}$ But even by focusing less on eastern issues during the 2002 election campaign the party failed to make an impact in the West.

Other factors that have hindered the party's attempts to gain credibility in the West are more the fault of the western branches themselves. Firstly the activities of some western PDS activists have brought ridicule. For example, the western PDS was described as 'a bunch of immature Spontis' following the distribution of leaflets in Frankfurt in 2001, which suggested 16 year olds should be allowed to smoke marijuana. ${ }^{72}$ The aforementioned controversy surrounding the Hamburg party executive was another case of bad publicity for the western PDS. Overall the makeup of the western PDS is clearly a problem if the party is to grow and become consolidated there. Its activists are young, radical, politically inexperienced, and lack a long-term sense of allegiance to the party, hence the turnover of members is high. 
According to the former parliamentary party leader, Roland Claus, the stabilising of personnel in the West is vital if the western expansion is to succeed. ${ }^{73}$

The relentless smear campaigns waged by other parties, in particular the Christian Democratic Union (CDU) and the CSU, have not helped matters. While the infamous 'red socks' campaign led by the CDU (which equated the PDS with the SED of the past) backfired in the East, it did find resonance in the West. ${ }^{74}$ An additional factor which damages the party's image in the West is the fact that several groups within the PDS are monitored by the Office for the Protection of the Constitution, which western Germans might interpret as a sign that the party poses a threat to democracy. Meanwhile the Communist Platform attributes the party's lack of support in the West to the economic and social structure of western Germany and to its claim that there are too many 'beneficiaries of globalization' there. ${ }^{75}$

In addition to the factors which have hindered the PDS's western expansion for some time, there were specific reasons why the party's vote share in the West failed to grow in 2002. Firstly, the federal party leadership lacked charismatic personalities and was virtually unknown outside the eastern Länder. No western figures featured in the 2002 federal campaign, which provoked criticism from western activists. ${ }^{76}$ Secondly, the more natural choices for western left-wing voters, the SPD and the Greens, both played trump cards during the election campaign. In the case of the SPD this was a strong anti-war stance, in the case of the Greens, a campaign focusing on their best asset, the popular foreign minister, Joschka Fischer.

The party's inability to increase its support in the West in 2002 seemed to vindicate those who opposed the Westaufbau in principle, especially since the aim to appeal nationwide appeared to have cost votes in the East. However, Gabi Zimmer still maintained that the party could not be allowed to retreat into the East, for to do so 
would mean the end of 'any claim to socialism'. ${ }^{77}$ Her former deputy, Petra Pau MP, agreed that the PDS should continue to operate nation-wide in spite of the election defeat, $^{78}$ a view shared by the western Land branches. However long-standing opponents of the Westaufbau of the PDS like Christine Ostrowski called for an end to the 'crazy idea' that the PDS was a party for the whole of Germany. In her view, its eastern identity was the PDS's own trump card, one that should be played to its full advantage. $^{79}$

WEST BERLIN: A TESTING GROUND FOR THE PDS

Berlin is the only Land in the Federal Republic that comprises territory from the former GDR and the old West Germany. As such Berlin functions as a testing ground for the PDS's aspiration to become a modern socialist party for all Germans. Some of the most prominent PDS politicians at federal level, such as Gregor Gysi, originate from East Berlin, hence there is considerable overlap between the personnel and objectives of the federal party and the Berlin Land party. An added bonus is the high membership level in the eastern part of the city which gives the party a strong local base from which target West Germans on its doorstep. The Berlin PDS has around 14,500 members, although only around 500 live in the west of the city. ${ }^{80}$ Leading PDS politicians like Petra Pau have for years regarded the future of the Berlin PDS as city-wide or non-existent. ${ }^{81}$ However, logic suggests that the party may not be able to have it both ways. To become a socialist party for left-wingers throughout Berlin could lose votes in the East among those who support it as the only representative of eastern interests in the capital's local political system which is numerically dominated by west Berliners. This is essentially a microcosm of the dilemma faced by the 
federal PDS, namely how to exploit a territorial-cultural cleavage and a class cleavage at the same time.

Nevertheless West Berlin does offer the PDS certain advantages compared with the rest of western Germany, notably high levels of political activism in certain districts and a well-established left-wing/alternative scene, which for decades attracted radicals from other parts of West Germany. This helped the Greens to establish strongholds in fashionable inner-city areas of West Berlin such as Kreuzberg. Over the past decade some prominent former Greens have defected to the Berlin PDS especially since the formation of the Red-Green federal government. ${ }^{82}$ The PDS has also attracted former members of other very small left-wing extremist parties including the Socialist Unity Party of West Berlin (SEW), (a radical but insignificant ally of the SED which peaked in the 1970s), and a handful of ageing ex-KPD members. ${ }^{83}$ Other potential recruits include members of Berlin's Turkish, Greek and Kurdish communities. Party representatives also visit trade unions, women's groups and even secondary schools in the hope of winning support in the western part of the city. Another advantage for the party is that by virtue of its strength in Eastern parts of the city the PDS is very visible. Thus while the party is an irrelevance for most voters in the western Länder, it is hard for West Berliners to ignore it. The big disadvantage however is that many older West Berliners will always equate the PDS with 'the Communists' who threatened their livelihoods for 40 years. Even so, the party is represented in every local council (Bezirksverordnetenversammlung) in West Berlin, and as elsewhere hopes to build up support from below by demonstrating competence at local level.

Unlike PDS members in the western Länder who may have little first hand knowledge of their eastern comrades, PDS members from west Berlin do come into contact with members of their Land branch from the east of the city. However, 
cultural differences between members persist, even thirteen years after reunification. The Berlin party is subdivided into local branches in each of the city's 13 boroughs (Bezirke). While two boroughs now straddle the route of the old Berlin Wall, local branches in the outskirts of both eastern and western Berlin are largely devoid of members from 'the other side of town' and thus retain a distinctly western or eastern flavour. This is partly because the overall number of people who have moved from one side of the city to the other since reunification is believed to be very small. ${ }^{84}$

The 1999 Berlin Land election was considered a milestone in the local and federal PDS's struggle to become a nation-wide socialist party. The party's vote share rose two per cent to 4.2 per cent in West Berlin, although this was modest compared with a result of 39.5 per cent in the East. The party's western vote was highest in Kreuzberg (9.7 per cent). ${ }^{85}$ Just two years later, the Berlin PDS had the chance to improve on the 1999 result in unexpected new elections which were to transform the Berlin party from pariah to power.

The 2001 Berlin Land election was controversial right from the start due to the toppling of the city's grand coalition by the SPD and Greens with the help of the PDS. ${ }^{86}$ This action broke a long-standing taboo surrounding any form of cooperation with the post-communists in the city where capitalism and communism had rubbed shoulders for 40 years. The PDS's campaign was immediately taken over by Gregor Gysi, the party’s self appointed candidate for mayor of Berlin. It was the first time the PDS had used a single Land list for the whole city (with Gysi in first place), as opposed to separate lists in each borough. ${ }^{87}$ Right from the start, Gysi's campaign was directed at voters across the capital. He utilised a common tactic in Berlin elections, namely appealing to Berliners' pride in their home city. Conscious that many people regarded the PDS as a divisive force in the capital, he declared, 'I stand 
for bridges not walls'. ${ }^{88}$ Opinion polls showed that across Berlin Gysi had the highest recognition rating of all the mayoral candidates, ${ }^{89}$ and that the proportion of Berliners who would chose him as mayor, if they could elect one directly, was considerably higher than the proportion who normally voted PDS. ${ }^{90}$

The Berlin PDS argued that the two parts of the city faced the same problems, in particular, unemployment, which is at eastern German levels on both sides of the capital. $^{91}$ The 2001 Land election manifesto, entitled 'Together for Berlin', focused on economic and social issues, on the need to banish corruption from Berlin politics, and to deal with the city's catastrophic financial situation. ${ }^{92}$ However, immediately after the events of September $11^{\text {th }}$, the foreign policy of the federal PDS had a negative impact on the poll ratings of the Berlin PDS. September $11^{\text {th }}$ caused widespread sympathy for America, and support for the PDS, a party often critical of American foreign policy, fell. However, the US-led bombing of Afghanistan, supported by the German government, revived the PDS's electoral fortunes as it was able to regain support from those who did not approve of this course of action. ${ }^{93}$

The Berlin PDS's election strategies paid off. The party's final result in the Land election was 22.6 per cent, an increase of almost 5 per cent compared with 1999. In western Berlin, the PDS’s vote share rose from 4.2 per cent in 1999 to 6.9 per cent, an increase of over 28,000 votes. Compared with recent Land elections in the western Länder this was an impressive performance, and provided encouragement for the federal party leadership’s hopes for electoral success across western Germany. However the result was still modest compared with the party’s result in eastern Berlin where it gained an unprecedented 47.6 per cent of the vote. ${ }^{94}$

The PDS attributed its success across Berlin to four factors: Gysi's charismatic leadership which had appealed to voters beyond the party’s usual clientele; voters' 
appreciation of the party's work at local council level; a strong desire for change and more social justice in the capital; and the party's outspoken condemnation of the USled military action in Afghanistan. ${ }^{95}$ More objective commentators agreed that two of these factors, namely Gysi and the Afghanistan issue, had helped the PDS reach beyond its regular electorate. $^{96}$ This was especially true in West Berlin. Once again the party's best result in the West was in Kreuzberg (18.7 per cent), a lively inner-city area, traditionally a Green stronghold, suggesting the claim to be Germany's only peace party found resonance there. ${ }^{97}$ In addition, the party may have provided an outlet for people who were simply frustrated with mainstream politics in the light of recent corruption scandals, or even for those who might otherwise have voted for parties of the far right. ${ }^{98}$ However, the fact remained that 77 per cent of PDS voters in Berlin lived in the East of the city. As was the case in both 1999 and 1995, most people who voted PDS did so because it was perceived as representing the interests of east Berliners in reunited Berlin's political system, and the same reason explains why 93 per cent of west Berliners chose not vote for the post-communist party.

The 2001 Berlin Land election eventually resulted in the creation of an SPD-PDS coalition, but this should not automatically be interpreted as a sign of the PDS's acceptance within the Federal Republic as a whole. It was not Chancellor Schröder's preferred option, just a year before the next federal election ${ }^{99}$ and was initiated by the SPD only after coalition negotiations with the Greens and free Democrats (FDP) had broken down. ${ }^{100}$ However, the highly respected former federal president, Richard von Weizsäcker, claimed that only a coalition of the two parties with the most support in each half of the city would be 'democratically just'. ${ }^{101}$ Even so, while 70.8 per cent of East Berliners had voted for one or other of the two governing parties, only 40.6 per cent of West Berliners had done so. ${ }^{102}$ 
TABLE 3: VOTES FOR THE PDS IN WESTERN BERLIN 1998-2002

\begin{tabular}{|l|l|l|}
\hline Election & Votes & Percentage \\
\hline Federal 1998 & 32,475 & 2.7 \\
\hline Land 1999 & 40,979 & 4.2 \\
\hline Land 2001 & 69,041 & 6.9 \\
\hline Federal 2002 & 30,374 & 2.7 \\
\hline
\end{tabular}

Source: Calculated from figures provided by the Bundeswahlleiter.

The PDS's electoral performance in West Berlin in 2001 inevitably raised hopes for the 2002 federal election. As mentioned before, due to boundary changes two of the constituency seats the PDS had previously won now included areas of western Berlin, ${ }^{103}$ hence the need to conduct a campaign that would appeal to East and West Berliners alike. But the party’s results in Berlin at the 2002 federal election were disappointing in both halves of the city. As table three shows, its share of the vote in West Berlin was the same as in 1998 and the party’s success in 2001 was not repeated. The 2002 result suggested that the party's success in West Berlin a year earlier had been a one-off, attributable to the saliency of particular issues and a strong candidate. Disappointment with the PDS's record in the Berlin senate since then may also have been a factor. Since 2001 the controversial 'red-red' coalition has faced many difficult decisions due to Berlin’s financial crisis, notably over public sector workers' pay. 
In the long term, the PDS will either have to retain a very high level of support in the east of the capital, or make inroads into the West to secure its future there. Both the federal and local party leaderships favour the latter option, not least because party has been losing approximately 2,000 members in East Berlin per year. Until recently, it appeared that if the PDS could make it anywhere in Western Germany it would be in the inner city areas of western Berlin, renowned for high levels of left-wing activism. But now the party is no longer a player at federal level, the chance to establish a permanent support base in West Berlin may have passed. Overall, the dilemmas of the PDS in Berlin are essentially local manifestations of the overall problem the party faces, namely how to be a modern socialist party and the representative of eastern German interests simultaneously.

\section{CONCLUSION}

This article has shown how the leadership of the PDS has aspired to become a nationwide, 'modern socialist party', albeit one with special responsibility of the East. However, even if it is unintentional, election results and membership data show that the PDS is de facto an East German regional party. For the majority of its core supporters the party’s eastern German origins and culture are paramount, whereas for the western German minority it is a vehicle for the struggle against capitalism. Indeed, for over a decade, the PDS has been more than a party in the East, while in the West it is rather less than one. In the eastern Länder it has provided camaraderie and activities to replace those lost with the demise of the GDR - an eastern niche in today's western orientated German society for those used to the old Nischengesellschaft (niche society) of the past. Until 2002 its continued electoral 
success in the East suggested its development and maturation had kept pace with changes in the lives of its eastern voters. As a result it evolved from the party of the old GDR into the party of contemporary eastern Germany. However these factors continued to hinder its ability to establish itself in the west of the country.

The problems facing the PDS demonstrate the difficulties parties face by attempting to exploit a territorial-cultural cleavage and a class cleavage simultaneously. In the end, trying to become a genuine federal party without losing its core supporters may be the PDS's undoing. ${ }^{104}$ The evidence suggests that it was the PDS's eastern distinctiveness and the fact that it was not like the western-based parties that had hitherto been the key to its success. Paradoxically, its concentrated regional appeal earned it a place in the German party system at federal level.

However, recent elections suggest not only that the western expansion is doomed to failure, but also that the party may have no future beyond Land and local politics in eastern Germany. The disastrous result of the 2002 federal election inevitably provoked acrimonious internal debate regarding the very nature and identity of the PDS. Deep ideological rifts within the party became obvious, as did the underlying east-west conflict. Although the influence of western hardliners has been removed from the party executive, a split between the ideologically motivated on the one hand, and the regionally orientated on the other is not unthinkable. ${ }^{105}$

The federal chair, Lothar Bisky, maintains that the party only has a future as an allGerman party, ${ }^{106}$ and the new Party Programme (as yet unratified) commits the party to operate nationwide. ${ }^{107}$ However even in the highly politicised 1960s and 1970s, indigenous far left-wing parties failed to make an impact in West Germany. The likelihood of a socialist party 'made in East Germany' finding success in the West looks very slim indeed. 


\section{NOTES}

${ }^{1}$ For an overview of various scholars' and journalists' attempts to classify the PDS see Dan Hough, The Fall and Rise of the PDS in Eastern Germany', (Birmingham: Birmingham University Press, 2001), pp.13-38.

${ }^{2}$ Hough, The Fall and Rise, p.22. Hough considers many other European regional parties in this detailed examination of the PDS as the 'articulator of Eastern German interests'. See pp.45-71.

${ }^{3}$ Terms developed by Seymour M. Lipset and Stein Rokkan in Party Systems and Voter Alignments (New York: The Free Press, 1967), especially pp.9-13.

${ }^{4}$ For more detail see Joanna McKay, 'Keeping the Red Flag Flying: The Electoral Success of the PDS in East Berlin', Journal of Communist Studies and Transition Politics, Vol.16, No.3 (2000), pp.1-20.

${ }^{5}$ Partei des Demokratischen Sozialismus, Programm, January 1993, pp.1, 41.

${ }^{6}$ Parteiprogramm der PDS, Überarbeiteter Entwurf (Feb. 2003), section IV. www.pdsonline.de/programm/debatte/index.htm

${ }^{7}$ Programm der Partei des Demokratischen Sozialismus zur Bundestagswahl 1998, pp.7-8.

${ }^{8}$ Es geht auch anders: Nur Gerechtigkeit sichert Zukunft! Programm der PDS zur Bundestagswahl 2002, p.9.

${ }^{9}$ Frankfurter Allgemeine Zeitung, 9 April 1998.

${ }^{10}$ Christine Ostrowski and Ronald Weckesser, Brief aus Sachsen, 7 May 1996. Ostrowski also criticised the implantation of 'Politouristen' from the West German left into the East, for which she received a dressing-down from the party leadership. 'Zwischen DDR und Moderne', Die Zeit, 23 April 1998, p.4.

${ }^{11}$ Christine Ostrowski and Ronald Weckesser, Zweiter Brief aus Sachsen, 5 June 2000.

${ }^{12}$ See 'Diskussionsbeitrag zum zweiten Brief aus Sachsen,' PDS Landesverband Sachsen.

${ }^{13}$ Michael Chapra and Dietmar Wittich, Die Mitgliedschaft, der grosse Lümmel... Studie zur Mitgliederbefragung 2000 der PDS, Mai 2001, p. 17. www.pds-

online/daten/mitgliederbefragung_2000/index.htm.

${ }^{14}$ See André Brie, Die PDS in Ost und West - Fakten und Argumente statt Vermutungen, Berlin, August 2000, p.14.

${ }^{15}$ Brie, Die PDS in Ost und West, p.3.

${ }^{16}$ Wahlstrategie der PDS 2001/2002 (Draft, 10 April 2001), p.1

${ }^{17}$ See Brie, Die PDS in Ost und West, pp.3-4. Former party chair Gabi Zimmer appeared to share this view. See Wirtschaft und Markt, February 2001.

${ }^{18}$ Roland Claus, 'Ist die PDS noch zu retten, Herr Claus?’ Der Tagesspiegel, 11 Aug. 2002.

${ }^{19} 4,761$ members according to a press release issued on 19 Nov. 2002. Source: www.pds-

online.de/politik/presseerklaerungen/view_html?zid1035\&bs=1\&n+0

${ }^{20}$ Figures: www.pds-online.de/partei/daten/mitgliederzahlen/2001.htm. Between 1998 and 2001 the western branches gained over a thousand members, while the eastern branches lost 18,000.

${ }^{21}$ www.pds-online.de/partei/daten/sozial_altersstrktur.htm (as 23 Aug. 2001)

${ }^{22}$ www.pds-online.de/partei/daten/sozial_altersstrktur.htm (as 23 Aug. 2001)

${ }^{23}$ Michael Chapra and Dietmar Wittich, Die Mitgliedschaft, der grosse Lümmel... Studie zur Mitgliederbefragung 2000 der PDS, Mai 2001, p.25. At the end of 2002 the total proportion of female PDS members was 45.7 per cent. (www.pds-online.de/partei/daten/frauenanteil.htm)

${ }^{24}$ Brie, Die PDS in Ost und West, pp.14, 24.

${ }^{25}$ Brie, Die PDS in Ost und West, p.14.

${ }^{26}$ Gabi Zimmer directly attacked the Hamburg PDS in her speech at the annual party conference in 2001. See ‘Frieden! Gerechtigkeit weltweit!’ Rede Der Vorsitzenden der PDS, Gabi Zimmer, 2. Tagung des 7. Parteitages der PDS, 7 Oct. 2001.

27 'Streit in Hamburgs PDS beigelegt?' Neues Deutschland, 2 May 2002.

${ }^{28}$ Gabi Zimmer has spoken of 'cultural alienation between the eastern and western left', Der Tagesspiegel, 4 Feb. 2001. See also Brie, Die PDS in Ost und West, p.2.

${ }^{29}$ Chapra and Wittich, Die Mitgliedschaft, p.17.

${ }^{30}$ Brie, Die PDS in Ost und West, p.18.

31 'Ich liebe Deutschland'. Taz-Interview mit Gabi Zimmer, die tageszeitung, 28 Oct. 2000, p.3.

${ }^{32}$ Her fiercest critic was westerner, Winfried Wolf. See Wolf, 'PDS-Deutschtümelei', Junge Welt, 4 Nov. 2000.

${ }^{33}$ Erhard Crome, ‘Wer pfeift auf die Fahnen?’ wwww.pds-online.de/politik/aktuell, 3 Nov. 2000.

${ }^{34}$ Winfried Wolf, 'PDS-Deutschtümelei', Junge Welt, 4 Nov. 2000. 
${ }^{35}$ They were Diether Dehm, the most prominent western activist, and Uwe Hiksch. In total, five of the 20 members of the 2002-03 executive came from western Germany.

${ }^{36}$ See the submission to the federal party conference 28-29 June 2003 by over a hundred western German members, including seven Land chairs/speakers, 'PDS-Konflikt - Ost-West-Konflikt?' (www.pds-online.de/as/vorstandswahl/erklaerungen)

${ }^{37}$ Three westerners were elected (of 20 executive members). Former deputy chair, Diether Dehm, who was widely blamed for the party's leadership crisis, stood for reelection but was unsuccessful.

${ }^{38}$ Klaus Jann, 'Es ist unfair nur auf Prozent zu schauen', Neues Deutschland, 28 July 2000, p.16.

39 'Madonna des Neokommunismus', Spiegel-Online, 28/1998.

${ }^{40}$ Pressedienst Nr.11, 13 March 2003, PDS Bayern: Keine Wahlteilnahme, www.pds-online.de/

${ }^{41}$ Diether Dehm, Stärkerwerden - auch im Westen! 13 March 2000, p.7.

${ }^{42}$ Dietmar Bartsch, 'PDS zieht überall, wo sie angetreten ist, in hessische Kommunalparlamente ein', Press release, 19 March 2001.

${ }^{43}$ For information on the Kommunalforum West see Dehm, Stärkerwerden, p.4.

${ }^{44}$ Diether Dehm, Stärkerwerden, pp.8-9.

${ }^{45}$ Meaning 'turbo pensioners', a term devised by Patrick Moreau to describe the thousands of East German pensions with limitless time and energy to devote to the PDS. See Moreau, 'Der Durchbruch der PDS im "Superwahljahr 1994” - Demokratie in der Krise', in Oberreuter (1996), p.236, cited in Hough, The Fall and Rise, p.124.

${ }^{46}$ 250,000 DM was invested in local elections in Hessen in March 2001. See Dietmar Bartsch, 'Westaufbau der PDS wird konsequent und langfristig fortgesetzt - PDS-Parteivorstand beschliesst Unterstützung des Kommunalwahlkampfes in Hessen,' Press release, 17 May 2000.

${ }^{47}$ Dietmar Bartsch, 'Ohne Moos nix los, deshalb “Gebt acht - und zwar in Euro!”, 10 July 2002, www.pds-berlin.de/spende.html.

48 'Frieden! Gerechtigkeit weltweit!' Rede Der Vorsitzenden der PDS, Gabi Zimmer, 2. Tagung des 7. Parteitages der PDS, 7 Oct. 2001.

${ }^{49}$ According to Gabi Zimmer the foreign policy of the red-green federal government was the main eason why western Germans should vote for the PDS. 'Das Interesse wächst wieder. Gabi Zimmer im SZ-Gespräch zur deutsch deutschen Befindlichkeit - Wahlkampf Ziel: Sechs Prozent plus X', Saarbrücker Zeitung, 13 Aug. 2002.

${ }^{50}$ Es geht auch anders: Nur Gerechtigkeit sichert Zukunft! Programm der PDS zur Bundestagswahl 2002, pp. 7-9.

${ }^{51}$ Die andere Politik wählen. Aufruf zur Bundestagswahl 2002, 7 Aug. 2002.

${ }^{52}$ Such groups were described as the 'Lebenselixier' of the PDS in the west by Diether Dehm, in Junge Welt, 26 April 2002.

${ }^{53}$ Gysi resigned after admitting he had made private use of airmiles earned on official business. However there was much speculation as to whether or not this was the only reason for Gysi's resignation. Some suggested it was prompted by investigations into the former Stasi connections of Berlin senators and MPs, while others believed he was frustrated due to the lack of progress made by the red-red government in Berlin. See Die Gründe für den Rücktritt Gregor Gysis, Gespräch mit Gabi Zimmer, Deutschlandfunk, 1 Aug. 2002, www.pds-

online.de/politik/aktuell/themen/ruecktritt_gysi/view_html?zid+6\&bs+1\&n+15; also ‘Gysi gibt Senatsmandat auf', Neues Deutschland, 1 Aug. 2002.

${ }^{54}$ For example, North Rhine Westphalia. See Presseerklärung zum Rücktritt von Dr. Gregor Gysi, www.pds-nrw.de/Gysi_Rueck2.htm.

55 'Die Landtagswahlen im Westen und die Zukunft der PDS', Mitteilungen der Kommunistischen Plattform, July 2000.

${ }^{56}$ Figures: Bundeswahlleiter. (www.bundeswahlleiter.de).

57 'Sozialdemokratisierung muss die PDS zerstören', Junge Welt, 27 Sept. 2002.

${ }^{58}$ For more details on PDS local councillors in the West see Jonathan Olsen, 'The PDS in Western Germany: An Empirical Study of PDS local politicians’, German Politics, Vol.11, No.1, (April 2002), pp.147-72.

${ }_{59}$ Manfred Klaus, Kommunale Mandate und Ämter der PDS, Report for the PDS, 29 June 2001, p.10. The PDS in NRW has since gained more seats at local level due to defections from other parties. See also 'PDS: die Führungskrise platzt mitten in den NRW-Wahlkampf', Spiegel Online, 18/2000.

60 'Die Landtagswahlen im Westen und die Zukunft der PDS', Mitteilungen der Kommunistischen Plattform, July 2000.

${ }^{61}$ Even Dietmar Bartsch, an advocate of the PDS's western expansion, had doubts. See Süddeutsche Zeitung, 25 May 2000. 
${ }^{62}$ Manfred Klaus, Kommunale Mandate und Ämter der PDS, Report for the PDS, 29 June 2001, p.9.

${ }^{63}$ PDS press release no. 13, 30 March 2001.

${ }^{64}$ PDS press release no. 12, 23 March 2001.

${ }^{65}$ Jörg Prelle, ‘Die Basisindianer kamen ganz schön ins Schwitzen’, Disput, April 2001.

${ }^{66}$ For an interesting description of the PDS in Bavaria see Uwe Hiksch, 'Leicht wird's nicht gerade im CSU-Ländschen...', Disput, Dec. 2000.

${ }^{67}$ Pressedienst 10, 7 March 2003: Zum Bürgerschaftswahl in Bremen.

${ }^{68}$ Results: Bundeswahlleiter.

${ }^{69}$ According to an Allensbach poll conducted in December 1999, 55 per cent of eastern German respondents and 65 per cent of western German respondents regarded the PDS as an eastern party as opposed to a left-wing party. Cited in Brie, Die PDS in Ost und West, p.21.

${ }^{70}$ See Schilderstürmer Bilderstürmer. Der Berliner Kulturkampf um Strassenschilder, a pamphlet published in June 1997 by the PDS Fraktion in the Berlin parliament,

${ }^{71}$ Nur Gerechtigkeit sichert Zukunft. Wahlstrategie der PDS 2001/2002 (Draft, 10 Apr. 2001).

72 'Fernes Land für die PDS’, Süddeutsche Zeitung, 6 February 2001.

${ }^{73}$ Roland Claus, 'Wir sind nicht Schröders Westentaschenreserve', Der Tagesspiegel, 22 Apr. 2001.

${ }^{74}$ For the 2002 federal election the CDU produced a booklet entitled 'Ten Reasons why the PDS must not be Permited a Share of Power'.

${ }^{75}$ Mitteilungen der Kommunistischen Plattform, July 2000.

76 'Sozialdemokrtisierung muss die PDS zerstören', Junge Welt, 27 Sept. 2002.

77 'Kein weiter so: Zukunft durch Erneuerung', Chair's speech at the PDS conference, Gera, 12 Oct. 2002.

${ }^{78}$ Interview with Petra Pau MP on InfoRadio Berlin-Brandenburg, 24 Sept. 2002.

79 'Den Ost-Trumpf nicht gezogen', Neues Deutschland, 24 Sept. 2002.

${ }^{80}$ Source: PDS Landesverband Berlin.

${ }^{81}$ In German 'gesamtstädtisch-sozialistisch oder gar nicht'. Source: Pau's manifesto for the 1998

federal election, http://members.aol.com.PDSholt249/

${ }^{82}$ Notably Berlin's economics senator, Harald Wolf.

${ }^{83}$ See 'PDS macht rüber nach Westberlin', Neues Deutschland, 1 Sept. 2001.

84 'Jung, hochgebildet, Westler - und PDS-Wähler', Der Tagesspiegel, 24 Oct. 2001.

${ }^{85}$ This was an increase of 4.4 per cent for the PDS in Kreuzberg, while the Greens' vote share dropped by 1.5 per cent there, suggesting that not only former Green voters were drawn to the PDS. Figures: Statistisches Landesamt Berlin.

${ }^{86}$ For an account of events leading to see Joanna McKay, 'From Pariah to Power: The Berlin Election of 2001 and the PDS Question', German Politics Vo.11, No. 2, pp. 21-38.

87 'Überholen, ohne einzuholen', Süddeutsche Zeitung, 16 July 2001.

${ }^{88}$ See PDS campaign leaflet 'Ich stehe für Brücken, nicht für Mauern.'

89 'Gysi bekanntester Spitzenkandidat im Berliner Wahlkampf', PDS press release, 15 Aug. 2001.

${ }^{90}$ In a poll in June 2001, 36 per cent of respondents claimed they would choose Gysi, compared with 30 per cent for the SPD's Wowereit and 22 per cent for the CDU's Steffel. 'Bürgermeisterfrage: PDS legt überall zu, Gysi sammelt auch im Westen Punkte’, Der Tagesspiegel, 22 June 2001.

${ }^{91}$ In June 2003, the unemployment rate in Berlin was 18 per cent. Source: Statistisches Bundesamt.

${ }^{92}$ See Miteinander für Berlin. Programm der PDS Berlin zu den Abgeordnetenhauswahlen am 21. Oktober 2001.

93 'Gegen den Wind', Süddeutsche Zeitung, 17 Oct. 2001.

${ }^{94}$ Elections results: Bundeswahlleiter.

${ }^{95}$ Information on the Results of the elections to the Berlin City Parliament, PDS-Online, 26 Oct. 2001.

${ }^{96}$ The view of Oskar Niedermayer of Berlin's Free University, 'Der Gysi Effekt', Der Tagesspiegel, 23 Oct. 2001.

97 'Aufschwung West', Der Tagesspiegel, 23 Oct. 2001.

${ }^{98}$ The view of Dieter Roth of the Forschungsgruppe Wahlen, 'Nasenstüber für den Westen', Der Tagesspiegel, 23 Oct. 2001. Far right parties combined only polled 2.2 per cent across Berlin in 2001, compared with 3.5 per cent in 1999.

${ }^{99}$ In an interview in the French newspaper, Le Monde, Chancellor Schröder expressed his preference for a 'traffic light' coalition, and hinted that financial aid for the capital would be more forthcoming if this were the outcome of negotiations. See 'Gregor Gysi sieht rot-rot', Süddeutsche Zeitung, 24 Oct. 2001.

${ }^{100}$ For more detail see McKay, 'From Pariah to Power', pp. 21-38.

101 'SPD und PDS reden über Inneres', Neues Deutschland, 11 Dec. 2001. 
${ }^{102}$ Calculated from figures supplied by the Landeswahlleiter für Berlin.

${ }^{103}$ Constituency 76 now comprises the old East Berlin area of Mitte, plus the West Berlin areas

Wedding and Tiergarten. Constituency 84 comprises the western area Kreuzberg and the eastern area Friedrichshain.

${ }^{104}$ Other scholars have expressed scepticism about the party's ability to represent eastern interests while simultaneously striving to become a 'nation-wide socialist alternative'. See for example Henry Krisch, 'Searching for Voters: PDS Mobilisation Strategies, 1994-97', in Peter Barker, The Party of Democratic Socialism. Modern Post-Communism or Nostalgic Populism? (Amsterdam \& Atlanta: Rodopi, 1998), pp.47-8; Günter Minnerup, 'The PDS and the Strategic Dilemmas of the German Left', in Barker, The Party of Democratic Socialism, pp.216-18.

${ }^{105}$ Bisky acknowledged that thee was a danger that the party would split in two. 'Bisky steht zur Not als Chef bereit', Der Tagesspiegel, 6 May 2003.

106 'Bisky steht zur Not als Chef bereit', Der Tagesspiegel, 6 May 2003.

${ }^{107}$ Parteiprogramm der PDS, Überarbeiteter Entwurf (Feb. 2003), section IV. www.pdsonline.de/programm/debatte/index.htm 